\title{
The Current Teaching Situation and Countermeasures of "Tibetan String Hu" Performance Course in Nationality Universities
}

\author{
Lian Zhou \\ Sichuan Minzu College \\ Kangding, Sichuan, 626001, China
}

\begin{abstract}
Tibetan String Hu" is the most characteristic string instrument in Tibetan areas of China, and nationality universities are important fields for its inheritance and development. Through in-depth investigations and studies of various nationality universities, it is found that the curriculum setting, teaching content and teaching mode need to be reformed and improved. Starting from the current teaching situation, this work proposed reasonable innovation strategies and reform approaches for the current teaching of "Tibetan String Hu" performance course with the help of new teaching concepts, so as to achieve the improvement of the "Tibetan String $\mathrm{Hu}^{\prime}$ teaching level, and realize better inheritance and development of the "Tibetan String $\mathrm{Hu}$ " performance art.
\end{abstract}

Keywords-Nationality universities; "Tibetan String $\mathrm{Hu}$ "; Current teaching situation; Reform; Innovation

\section{INTRODUCTION}

"Tibetan String $\mathrm{Hu}^{\prime}$ is the most important playing instrument in the Tibetan folk song and dance art, which combines "poetry, song, dance and music". Its tone is deep and rich, and it has become a unique Tibetan elf on the snowy plateau, which is mainly popular in Garze Tibetan Autonomous Prefecture, Tibet Changdu District, Qinghai Yushu Tibetan Autonomous Prefecture and Yunnan Diqing Tibetan Autonomous Prefecture[1]. At present, due to the lack of reasonable curriculum setting, single teaching content and lack of standardization, traditional teaching mode and other problems, teachers are struggling to teach and students are likely to get confused. The author believes that in order to improve the teaching level of the "Tibetan String $\mathrm{Hu}^{\prime}$ performance course, it is necessary to conduct in-depth discussions from the following aspects.

\section{The Significance of Constructing "Tibetan STRING Hu" PERformance COURSE}

"Tibetan String $\mathrm{Hu}$ " is a traditional string instrument of the Tibetan nationality in China with a long history. After longterm accumulation and creation, it has gradually formed a kind of traditional music art of the Tibetan nationality, with distinct national characteristics. As a part of Chinese national music culture, "Tibetan String $\mathrm{Hu}^{\prime}$ is of great significance in constructing the performance course in nationality universities, which is conducive to perfecting the national music system, cultivating national creative talents and carrying forward the Chinese national culture.

\section{A. It is the way to perfect the national music system}

Kodaly, a famous music educator in Hungary, once said: "If a nation does not attach importance to its own folk music, and does not base its own music culture on its national music, it will either drift like a floating lotus in the world culture or irretrievably disappear into the international culture"[2]. As a string instrument of nationality minorities in China, "Tibetan String $\mathrm{Hu}^{\prime \prime}$ is deeply loved by the masses. Under the background of the world's diversified music culture, the national musical instrument is impacted by the western musical instrument in its process. Under such circumstances, nationality universities have obligations to make efforts to promote the prosperity and development of minority music education. They should start from the rapid advancement of traditional educational concepts and educational models, and further improve the national music education system through the construction of "Tibetan String Hu" performance courses, so as to achieve the organic fusion of multiple music culture.

\section{B. It is the need to cultivate national creative talents}

"Americans have reflected on education. They believe that it is necessary to pay attention to art education including music and cultivate a large number of scientific and technological talents if the United States wants to become the most technologically advanced country in the world"[3]. That is to say, national music education can maximize the imagination and creativity of students to a certain extent. In 1994, the United States added the "Arts Curriculum including Music as a Core Discipline" into the legislation and implemented the "Comprehensive Phonology Teaching Method" from primary schools to universities nationwide. The success of American music teaching shows that the cultivation of creative talents in China requires innovation based on preserving the essence of traditional music culture, so as to build a national music teaching system and cultivate national creative talents.

\section{It is the path to promote and develop Chinese national music culture}

Qian Mu once said: "Culture is also the life of a nation. If a nation has no culture, it means that there is no life. Therefore, all so-called cultures must have a long-lasting spirit" [4]. Tibetan music culture is an important part of Chinese minority music culture, which contains Tibetan historical culture and emotional connotation and condenses the spirit and soul of the Tibetan people. Only through the in-depth study of "Tibetan String $\mathrm{Hu}^{\prime}$, the most representative national string instrument 
in Tibetan areas, can people truly understand the rich and colorful history and culture of Tibetan nationality, so as to lay a solid foundation for inheriting and carrying forward the national music culture. Nowadays, with the deepening of people's social and cultural values of national music education, all nationality universities have gradually realized the importance of constructing a minority music education system, and the responsibility of carrying forward and developing national music culture. Only by constantly strengthening the construction of national music education system can the sustainable development of national music culture be realized.

\section{The CuRRENT TEACHING SituAtion OF "TiBETAN STRING Hu" PERFORMANCE COURSE IN NATIONALITY UNIVERSITIES}

In recent years, nationality universities have adopted the "Tibetan String Hu" performance course as a public music elective course for the whole students, which is mainly for music-loving students in the second-level college. From the current teaching situation, there exist the following problems:

\section{A. Unreasonable curriculum setting of the "Tibetan String Hu" performance course}

In the process of teaching practice, it is found that, first, most elective students do not have any music foundation or basis for instrumental performance, and their purpose is only to complete elective credits. However, it is more difficult to learn string music than other instruments. As a result, facing different levels of teaching objects will eventually lead to the slow progress of teaching. What is worse, most of the elective students will gradually lose confidence in this course and only a small number of students with a certain musical foundation will continue to learn. Second, string instruments have a longer learning period than other instruments. The learning period of "Tibetan String $\mathrm{Hu}$ " is only two semesters, 10 weeks in each semester and one class per week. Students only have the opportunity to practice in class. According to the calculation of ten lessons each semester, students can only learn the most basic playing skills in two semesters. Most students can only reach the primary level after two semesters, and the further improvement of students is limited by class hours.

\section{B. Simple teaching content without standardization}

As a string instrument, "Tibetan String $\mathrm{Hu}^{\prime}$ is more difficult than other instruments. At present, there are fewer teaching materials in the teaching of "Tibetan String $\mathrm{Hu}^{\prime}$, and the teaching track is relatively simple. It has not collected and sorted out new tracks for a long time but is limited to a few simple traditional folk songs. At the same time, there is a lack of professional Tibetan string teachers. Nationality universities mainly assist the teaching by hiring the famous "Tibetan String $\mathrm{Hu}$ " inheritors. Therefore, there is no syllabus or fixed teaching material. This impromptu teaching is highly random, and students lack systematic training of basic performance knowledge, as a result, students' performance level cannot be improved. Moreover, the teaching content of "Tibetan String $\mathrm{Hu}$ " lacks standardization. No matter the playing method or the playing skill of "Tibetan String Hu", different players have different opinions, for example, in terms of the string-pressing of "Tibetan String Hu", some people use the central part of their first disjoint prominence, some people use their fingertips, and some people use the finger prominence between the first and second joint. Various postures will directly affect the teaching effect.

\section{Traditional teaching mode of "Tibetan String $\mathrm{Hu}^{\prime}$ performance course}

The current teaching form of "Tibetan String $\mathrm{Hu}$ performance course is mainly based on individual guidance and group training. All students practice in a spacious rehearsal room. Teachers first explain and demonstrate the performance, and then guided one by one, but this form of teaching does not give full play to the main role of students. At the same time, due to the constraints of class hours and the content of the textbooks, teachers only impart "Tibetan String Hu" playing skills, but ignore the knowledge of the instrumental music theory of "Tibetan String Hu" itself. In the long run, students will lack music literacy cultivation. In this case, even if students have a certain level of performance, they are unable to connect the music piece with its connotation and integrate emotion into the work due to their lack of understanding. This kind of teaching mode lacking imagination and creativity directly affects the enthusiasm of students to learn, and the teaching effect is not good.

\section{COUnTERmeasures OF "Tibetan String Hu" PERFORMANCE COURSE IN NATIONALITY UNIVERSITIES}

As far as the current teaching situation of "Tibetan String $\mathrm{Hu}$ " performance course in nationality universities is concerned, improving teaching level, inheriting and developing the performance of "Tibetan String Hu" performance course require us to propose new innovative strategies and reform approaches with the help of new teaching concepts.

\section{A. Changing curriculum setting from "general" to "specialized"}

"The curriculum is the core of the training program and the key to implementing the training of talents" [5]. In order to effectively inherit and develop the performance of "Tibetan String Hu", the "Tibetan String $\mathrm{Hu}^{\prime}$ performance course is supposed to reform in terms of curriculum setting according to a series of problems in opening public elective courses for "Tibetan String $\mathrm{Hu}^{\prime}$ in nationality universities. It should be changed from "general" to "specialized" in terms of the course nature and the setting of course hours. The course nature should be changed from public elective to specialized elective, and only for musicology and music performance students, so that the "Tibetan String Hu" art can be better passed down and developed in nationality universities; in addition, the "Tibetan String $\mathrm{Hu}^{\prime}$ learning period is relatively long, so the opening period of the "Tibetan String Hu" performance course should be adjusted from one semester to three semesters, 18 weeks per semester. What is more, students should be allowed to take this course constantly, which can ensure the continuity of "Tibetan String $\mathrm{Hu}^{\prime}$ performance teaching and is beneficial to the improvement of teaching effectiveness. 


\section{B. Enriching and standardizing the teaching content so as to improve students' interest in learning}

As far as the current teaching content is concerned, there is a lack of systematic and targeted "Tibetan String $\mathrm{Hu}^{\prime \prime}$ performance materials. Tibetan folk works, especially those that can express national emotions and interpret national music, should be incorporated into the teaching materials of "Tibetan String $\mathrm{Hu}^{\prime}$ performance teaching. Students can experience the charm of Chinese traditional folk music culture through the unique classic textbook content that can reflect the advantages of national music, so that they will not blindly advocate western classical music, but revere and have confidence in Chinese traditional music. Therefore, excellent national musicians should be hired to provide professional technical guidance in the selection of "Tibetan String $\mathrm{Hu}^{\text {" teaching }}$ materials, and the inheritors of intangible cultural heritage should be hired to analyze and guide the content. At the same time, some teachers with a profound background in ethnomusicology should participate to work together to make the essence of the national music infiltrate every chapter of the textbook, even every line of text and every note. In addition, the playing methods and techniques of the "Tibetan String Hu" should be further clarified, and a set of standardized and unified string playing system should be formed, which undoubtedly plays an important role in improving the teaching level of "Tibetan String $\mathrm{Hu}^{\prime}$ and cultivating students' enthusiasm for learning.

\section{Innovating teaching mode to give play to students' initiative and innovation}

In order to cooperate with the curriculum nature reform from "general" to "specialized", the professional elective courses need to be adjusted from the collective class to a onethree group teaching class, that is, one teacher only instructs three students in each class. For one thing, the teaching instruction time is prolonged, for another, the group teaching style allows students to compare and learn from each other, which can exert students' subjective initiative and innovation. Furthermore, the adjustment of teaching forms is conducive to improving students' performance ability and enhances students' interest in learning "Tibetan String $\mathrm{Hu}$ ".From the traditional teacher's dominant class to the students' independent communication and questioning, students can improve their independent thinking and independent innovation learning ability. On the basis of students' mastering the good skills of "Tibetan String Hu", the teaching content should be "customized" according to the current classroom conditions and the flexible teaching design should be used to make students in the leading position. At the same time, not only should teachers' pay attention to the improvement of the performance of "Tibetan String Hu", but also impart the music theory knowledge. In the teaching process, organizing team performances is conducive for students to cooperating with each other in the classroom, so that they can find deficiencies, rethink and correct their own learning results, thus continuously improving the teaching effect. At the same time, students should be provided with more stage practice opportunities to perform on the stage and out of the campus.

\section{SUMMARY}

Tagore once said: "Music is the best means of national selfexpression. A country without its own music and art can only be dumb forever" [6]. At present, although the construction of "Tibetan String $\mathrm{Hu}^{\prime}$ performance course in nationality universities is in the growth stage, it will be mature with the joint efforts of the players and researchers. The author puts forward reasonable innovation strategies and reform approaches for the teaching of "Tibetan String $\mathrm{Hu}^{\prime}$ performance course, hoping to give some inspirations to the educators who study minority music in nationality universities. Nationality universities should also attach importance to the significance and importance of inheriting and developing minority music culture, and jointly contribute to the improvement of the national music education system, the cultivation of national creative talents and the promotion of Chinese national music culture.

\section{ACKNOWLEDGMENT}

This article is an outcome of the Quality and Teaching Reform Project of Higher Education Talent Training from 2018 to 2020: The Exploration and Practice on the Teaching of Local nationality Under the Training Mode of Applied Talents - Taking the Teaching of "Tibetan String Hu" as a Case Study.

\section{REFERENCES}

[1] Tian Liantao. Research on Tibetan Batang String Music[J]. Chinese Music, 2012, No. 1, p.40.

[2] Zhang Zhen. Inheritance of Local Music Culture in Music Education of Normal Universities[J]. Journal of Hubei University of Science and Technology, 2015, No. 8, p136.

[3] Luo Xiaohai. The Basic Idea of the Construction of "National Music Teaching System" in China-Taking the Construction of National Music and OA Learning System as an Example[J]. Sichuan Drama, 2014, No. 2, p.163.

[4] Han Yanting, Yin Aiqing. Reflections on Inheriting National Music Culture in School Music Education[J]. Journal of Northeast Normal University, No. 4, 2018, p.241.

[5] Gao Jie. Thoughts on the Cultivation of Music Education Talents in Colleges and Universities Under the Perspective of Teacher Professional Certification[J]. People's Music, No. 7, 2019, p.56.

[6] Lian Yun. Deficiency of Chinese Traditional Music in Professional Music Education[J]. Big Stage, 2015, No. 12, p.181. 